\title{
A preliminary study of heavy metals pollution risk in water
}

\author{
Raafat Abdeldayem ${ }^{1}$ D
}

Received: 2 April 2019 / Accepted: 1 October 2019 / Published online: 2 November 2019

(c) The Author(s) 2019

\begin{abstract}
This study seeks to find out the risk of heavy metal pollution in domestic water on human health. The size of samples was 50 domestic water, 50 urine, and 50 blood samples taken from subjects chosen of the different four districts during 2017. Trace metal analysis was done using atomic absorption spectrophotometer. The results showed alarming levels of heavy metal contamination that exceed national and international thresholds in several observed sites. Therefore, stricter standards may be needed in order to reduce overall population exposure.
\end{abstract}

Keywords Water $\cdot$ Patients $\cdot$ Urine $\cdot$ Trace elements $\cdot$ AAS

\section{Introduction}

Water contamination has multiple influences on the regional and countrywide health. Diseases related to contamination of drinking water constitute a major burden on human health (WHO 2017), and the evaluation of the quality of drinking water is one of the high priorities to avoid any health problems. The World Health Organization (2017) has provided guidelines for drinking water quality that may compromise the safety of drinking water. Major water pollutants are shown in Fig. 1 (Kumar Reddy and Lee 2012). Globally, heavy metals have been a serious threat to human health and ecosystem integrity (Ogbomida et al. 2018). Groundwater, in general, is not vulnerable to surface contamination since the contaminants are either decayed or diluted in unsaturated zone before reaching the water table, while surface water is susceptible to contamination (Sharma et al. 2017). Excess levels of heavy metals can damage human health and ecosystems (Ehya and Marbouti 2016). This study seeks to find out the risk of heavy metal pollution in domestic water on human health.

\section{Subjects and methods}

\section{Participants}

The preliminary research study was conducted during 2017 . In total, 50 subjects were selected who approved to participate in the study between 29 and 63 years old and classified into two groups:

Group 1 included 40 subjects ( 27 males and 13 females) drinking the water of ground origin with a mean age of $41.73 \pm 4.02$ as a main group.

Group 2 included ten subjects (five males and five females) drinking the water of surface origin with a mean age of $40.87 \pm 5.59$ as a control group.

\section{Sampling}

Water, urine, and blood samples were collected from the total subjects of four districts after having informed consent as mentioned in Table 1. Collection, stabilization, transportation, and storage of samples were done according to the standard methods (APHA 2012). Samples were carefully handled to avoid contamination.
Raafat Abdeldayem

raafat_mandour@hotmail.com

1 Mansoura University, Mansoura, Egypt 


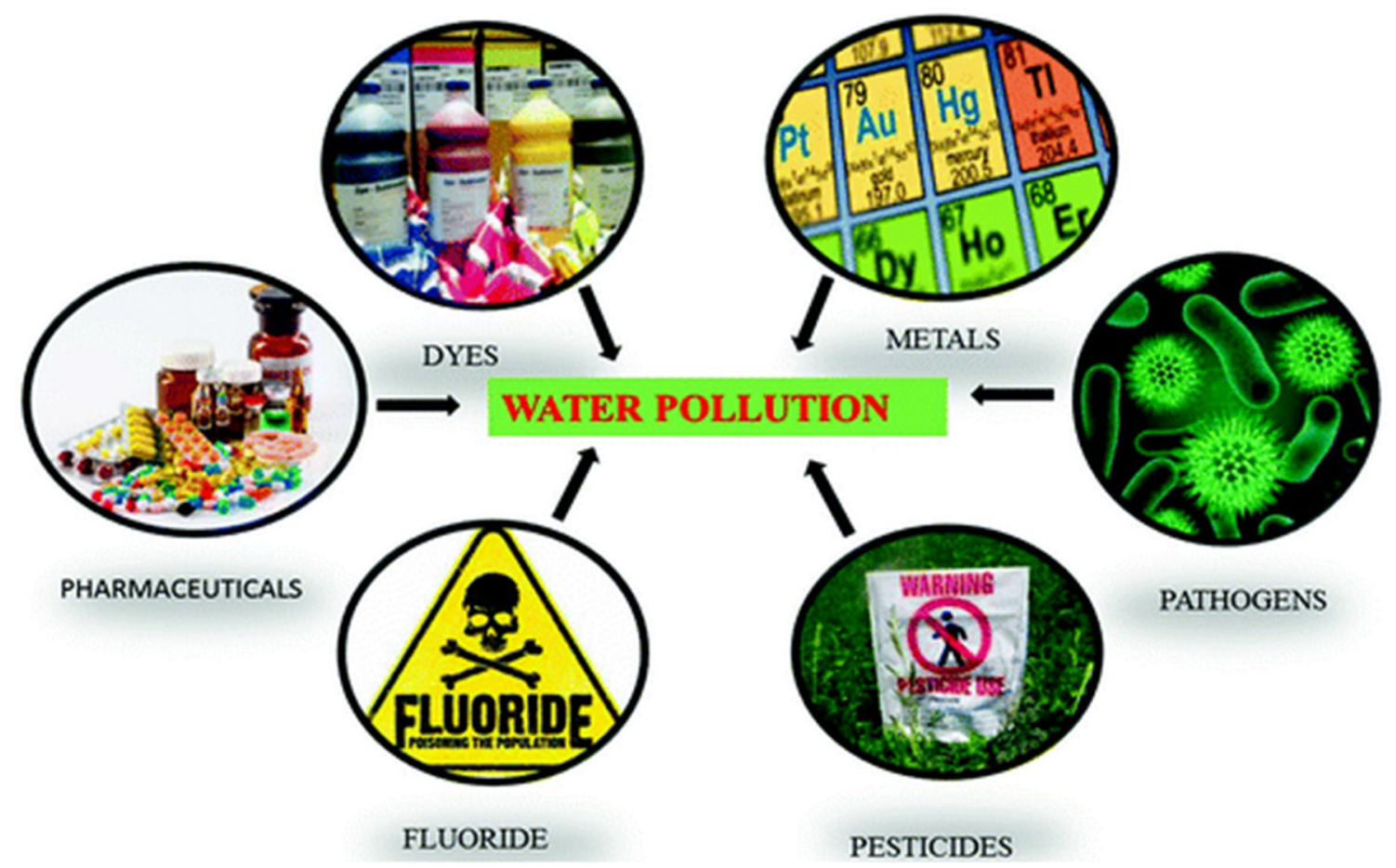

Fig. 1 Sources of water contamination (Kumar Reddy and Lee 2012)

Table 1 Districts and number of samples

\begin{tabular}{llllllc}
\hline No. & District name & Group & $\begin{array}{l}\text { No. of water sam- } \\
\text { ples and origin }\end{array}$ & $\begin{array}{l}\text { No. of urine } \\
\text { samples }\end{array}$ & $\begin{array}{l}\text { No. of blood } \\
\text { samples }\end{array}$ & Mean age \pm SD \\
\hline A & Aga & Group 1 & 20-Ground & 20 & 20 & $41.73 \pm 4.02$ \\
B & Mit Ghamr & & 20-Ground & 20 & 20 & \\
C & Mansoura & Group 2 & 5-Surface & 5 & 5 & $40.87 \pm 5.59$ \\
D & Talkha & & 5-Surface & 5 & 5 & \\
Total & & 50 & 50 & 50 & \\
\hline
\end{tabular}

SD, standard deviation

\section{Methods}

Four heavy metals, lead $(\mathrm{Pb})$, iron $(\mathrm{Fe})$, manganese $(\mathrm{Mn})$, and cadmium $(\mathrm{Cd})$, were analyzed in domestic water and urine samples using graphite furnace AAS. All reagents and devices were checked beforehand for any kind of contamination with these trace elements. Blood samples $(10 \mathrm{ml})$ were subjected to laboratory assessment of liver functions, kidney functions, and complete blood count on auto-analyzer and Coulter counter, Beckman Instrument Inc., USA. The results were compared with the permissible limits of EMH (2007) and WHO (2017) standards for drinking water and kit references.

Statistical analysis was done for all samples by SPSS program.

\section{Results and discussion}

This paper reviews quite a few heavy metal contamination-related studies in several cities from Dakahlia region. These heavy metals have been selected for their importance to the health and availability of laboratory testing capability. Tables 2 and 3 show high values of iron, manganese, lead, and cadmium than the permissible limits of WHO (2017), EMH (2007), and Iyengar (1985). The mean concentration of iron in some water samples was significantly high; this came in accordance with the previous studies done by Niu et al. (2006) and in agreement with that explained by Lasheen et al. (2008). There is a significant positive correlation between hemoglobin, creatinine, and aspartate transaminase with iron levels of group 1 
Table 2 High levels of heavy metals in water samples

\begin{tabular}{llllll}
\hline No./district & Sample no. & $\mathrm{Cd}$ & $\mathrm{Pb}$ & $\mathrm{Fe}$ & $\mathrm{Mn}$ \\
\hline WHO (2017) & & 0.003 & 0.01 & 0.3 & 0.4 \\
EMH (2007) & & 0.003 & 0.01 & 0.3 & 0.4 \\
Group 1 & & & & & \\
A-Aga & & & & & \\
& 4 & 0.008 & & & \\
B-Mit Ghamr & & & & & \\
& 1 & & 0.45 & 0.43 \\
& 2 & & 0.015 & & \\
& 4 & & & & \\
Group 2 & & & & & \\
C-Mansoura & & 0.004 & 0.016 & & \\
& 2 & 0.005 & & & \\
& 5 & & & & \\
D-Talkha & & 0.004 & & 0.014 & \\
& 5 & & & &
\end{tabular}

Table 3 High levels of heavy metals in urine samples

\begin{tabular}{llllll}
\hline No./district & Sample no & $\mathrm{Cd}$ & $\mathrm{pb}$ & $\mathrm{Fe}$ & $\mathrm{Mn}$ \\
\hline $\begin{array}{l}\text { Iyengar GV, 1985 } \\
\text { median reference }\end{array}$ & & 0.8 & 11 & 129 & 0.6 \\
$\begin{array}{l}\text { Group 1 } \\
\text { A-Aga }\end{array}$ & 4 & & & & \\
& & 0.81 & & & \\
B-Mit Ghamr & 1 & & & & \\
& 2 & & & 149 & 0.67 \\
& 4 & & 15 & & \\
Group 2 & & & 13 & & \\
C-Mansoura & & & & & \\
& 2 & 0.85 & 11.5 & & \\
& 5 & 0.87 & & & \\
D-Talkha & 3 & 0.83 & & & \\
& 5 & & 11.3 & \\
\hline
\end{tabular}

subjects. This agrees with the study done by Jadhav et al. (2007). Patients suffering from liver cirrhosis related to contaminant domestic water mainly with iron. If drinking water obtained from a well water source, it may be wise to have the water checked for manganese to ensure the level is below the current guideline level established by the ATSDR (2012). The household plumbing fixture made up of lead may contribute lead in the drinking water. These agree with Jennings et al. (1996), who reported that exposure to lead is cumulative over time and high concentration of lead in the body can cause permanent damage to the central nervous system and kidney. The cadmium concentration in the groundwater samples of the area found higher than the permissible limit. This came in consistency with previously reported studies done by Jarup et al. (2000) and Chen et al. (2006), who reported that chronic cadmium exposure can induce renal tubular damage. Serum creatinine, aspartate transaminase, and hemoglobin were significantly high in blood samples; this gives positive indication with that of cadmium in water and urine of group 1 subjects compared to group 2, as mentioned in Table 4.

Positive correlation exists between cadmium, manganese, lead, and iron for both water and urine samples in the study area. It means there is a source of pollution that increases these heavy elements' concentration in water. The presence of $\mathrm{Pb}, \mathrm{Cd}, \mathrm{Mn}$, and $\mathrm{Fe}$ in the study area could attribute to the anthropogenic origin. In this paper, the drinking water health risk assessment of heavy elements in this region is preliminary.

\section{Conclusion}

An immediate and sustainable collective action to control the pollution level is highly recommended, as this issue poses a severe public health threat. The results of this study may be limited due to small sample size; however, it can be considered as a starting point for a larger study later.
Table 4 Blood sample values expressed as mean $\pm \mathrm{SD}$

\begin{tabular}{|c|c|c|c|c|c|c|c|}
\hline \multirow[t]{3}{*}{ Group } & \multicolumn{7}{|l|}{ Parameters } \\
\hline & \multicolumn{3}{|c|}{ Liver function } & \multirow{2}{*}{$\begin{array}{l}\text { Kidney function } \\
\text { Creatinine (mg/dl) }\end{array}$} & \multicolumn{3}{|l|}{$\mathrm{CBC}$} \\
\hline & Bil (mg/dl) & AST (IU/l) & ALT (IU/l) & & $\mathrm{Hb}(\mathrm{gm} / \mathrm{dl})$ & $\mathrm{RBC}$ & WBC \\
\hline Group 1 & $1.30 \pm 0.29$ & $52.05 \pm 7.09$ & $22.12 \pm 4.05$ & $1.3 \pm 0.18$ & $14.83 \pm 0.59$ & $6.7 \times 106$ & $9 \times 103$ \\
\hline Group 2 & $0.43 \pm 0.03$ & $23.89 \pm 3.67$ & $20.09 \pm 4.01$ & $0.56 \pm 0.12$ & $13.55 \pm 0.77$ & $5.5 \times 106$ & $7 \times 103$ \\
\hline
\end{tabular}

Bil, bilirubin, AST, aspartate transaminase; ALT, alanine transaminase; Hb, hemoglobin; RBC, red blood corpuscles; WBC, white blood corpuscles; $\mathrm{CBC}$, complete blood count 
Acknowledgements I wish to thank the study participants for their contribution to the research.

Funding None.

\section{Compliance with ethical standards}

\section{Conflict of interest None.}

Ethical approval Consent of the patients for samples was obtained before enrolling in the study.

Open Access This article is distributed under the terms of the Creative Commons Attribution 4.0 International License (http://creativeco mmons.org/licenses/by/4.0/), which permits unrestricted use, distribution, and reproduction in any medium, provided you give appropriate credit to the original author(s) and the source, provide a link to the Creative Commons license, and indicate if changes were made.

\section{References}

Agency for Toxic Substances and Disease Registry (ATSDR) (2012) Toxicological profile for manganese. U.S. Department of Health and Human Services, Public Health Service, Atlanta, GA

American Public Health Association (APHA) (2012) Standard methods for the examination of water and wastewater, 27th edn. APHHA, Washington, DC

Chen L, Lei L, Jin T, Nordberg M, Nordberg GF (2006) Plasma metallothionein antibody, urinary cadmium, and renal dysfunction in a Chinese type 2 diabetic population. Diabetes Care 29(12):2682-2687

Egyptian Ministry of Health (EMH) (2007) Standards and specifications of water quality for drinking and domestic uses. Internal Report 1-8

Ehya F, Marbouti Z (2016) Hydrochemistry and contamination of groundwater resources in the Behbahan plain, SW Iran. Environ Earth Sci 75:45

Iyengar GV (1985) Concentrations of 15 trace elements in some selected adult human tissues and body fluids of clinical interest from several countries: results from a pilot study for the Establishment of reference values. F.R.G. Nuclear Research Center Juelich, Juelich

Jadhav SH, Sarkar SN, Patil RD, Tripathi HC (2007) Effects of subchronic exposure via Drinking water to a mixture of eight water-contaminating metals: a biochemical and Histopathological study in male rats. Arch Environ Contam Toxicol 53(4):667-677

Jarup L, Hellstrom L, Alfven T, Carlsson MD, Grubb A, Persson B (2000) Low Level exposure to cadmium and early kidney damage: the OSCAR study. Occup Environ Med 57:668-675

Jennings GD, Sneed R, Clair MB (1996) Metals in drinking water. No. AG: 473-1, North Carolina Cooperative Extension Service, Goldsboro, NC

Kumar Reddy DH, Lee SM (2012) Water pollution and treatment technologies. J Environ Anal Toxicol 2:e103

Lasheen MR, Sharaby CM, El-Kholy NG, Elsherif IY, El-Wakeel ST (2008) Factors influencing lead and iron release from some Egyptian drinking water pipes. J Hazard Mater 160(2-3):675-680

Niu ZB, Wang Y, Zhang XJ, He WJ, Han HD, Yin PJ (2006) Analysis of influence factors and control methods on iron release phenomenon in drinking water distribution system. Huanjing Kexue 27(2):310-314

Ogbomida ET, Nakayama S, Bortey-Sam N, Oroszlany B, Tongo I, Enuneku AA, Ogbeide O, Ainerua MO, Fasipe IP, Ezemonye LI, Mizukawa H, Ikenaka Y, Ikenaka M Ishizuka (2018) Accumulation patterns and risk assessment of metals and metalloid in muscle and official of free-range chickens, cattle and goat in Benin City, Nigeria. Ecotoxicol Environ Saf 151:98-108

Sharma DA, Rishi MS, Keesari T (2017) Evaluation of groundwater quality and suitability for irrigation and drinking purposes in southwest Punjab, India using hydro chemical approach. Appl Water Sci 7(6):3137-3150. https://doi.org/10.1007/s1320 1-016-0456-6

World Health Organization (2017) Guidelines for drinking-water quality. Fourth edition Incorporating the first addendum. pp 1-631

Publisher's Note Springer Nature remains neutral with regard to jurisdictional claims in published maps and institutional affiliations. 